\title{
Polymorphisms in RAD5I and their relation with breast cancer in Saudi females
}

This article was published in the following Dove Press journal:

OncoTargets and Therapy

II January 2016

Number of times this article has been viewed

\author{
Sahar Tulbah' \\ Huda Alabdulkarim² \\ Mohammad Alanazi ${ }^{3}$ \\ Narasimha Reddy Parine ${ }^{3}$ \\ Jilani Shaik ${ }^{3}$ \\ Akbar Ali Khan Pathan ${ }^{3}$ \\ Abdullah Al-Amri ${ }^{3}$ \\ Wajahatullah Khan ${ }^{4}$ \\ Arjumand Warsy' \\ 'Department of Biochemistry, \\ College of Science, King Saud \\ University, Center of Scientific and \\ Medical Colleges, ${ }^{2}$ Department of \\ Hematology/Oncology, King Fahad \\ Medical City Hospital, Comprehensive \\ Cancer Center, ${ }^{3}$ Department of \\ Biochemistry, College of Science, \\ King Saud University, ${ }^{4}$ Basic Sciences \\ Department, College of Science \\ and Health Professions, King Saud \\ bin Abdulaziz University for Health \\ Sciences, Riyadh, Saudi Arabia
}

Correspondence: Arjumand Warsy Department of Biochemistry, College of Science, King Saud University, Center of Scientific and Medical Colleges, PO Box 22452, Riyadh II495, Saudi Arabia Email aswarsy@ksu.edu.sa

\begin{abstract}
The present study aimed at investigating the relationship between rs1801320 $(\mathrm{G}>\mathrm{C})$, rs1801321 (G>T), and rs2619681 (C>T) RAD51 gene polymorphisms and the risk of breast cancer development in Saudi females. The genotypes were analyzed using TaqMan genotyping assay and polymerase chain reaction-restriction fragment length polymorphism. The genotype and allele frequencies were computed using chi-square or Fisher's exact test (two-tailed) by SPSS 21 software. The results showed that rs $1801321 \mathrm{G}>\mathrm{T}$ GG genotype and $\mathrm{G}$ allele frequency were strongly $(P<0.0001)$ related to an elevated risk of breast cancer, while the mutant $\mathrm{T}$ allele appeared to provide protection against breast cancer development as observed from the significantly lower $(P<0.0001)$ frequencies of the TT and GT genotypes in cancer patients compared to the healthy controls. The variant $\mathrm{rs} 1801320 \mathrm{G}>\mathrm{C}$ showed no significant differences in the frequencies of the genotypes and alleles in the patients and the control groups. The CC genotype and $\mathrm{C}$ allele frequency of rs2619681 (C>T) variant were significantly $(P=0.012)$ higher in cancer patients, whereas the $\mathrm{T}$ allele showed a protective effect against cancer development. The frequencies of the three single-nucleotide polymorphisms did not differ in cancer patients with different tumor grades and human epidermal growth factor receptor 2 status (+ or -). However, the genotype frequency of $\operatorname{rs} 1801320(135 \mathrm{G}>\mathrm{C})$ differed in the patients with estrogen receptor (ER)+ and ER-, where $\mathrm{CC}$ genotype showed a significantly higher prevalence in the females with ER- who were suffering from breast cancer. In addition, the frequency of C allele of rs2619681 (C>T) was also significantly higher in the breast cancer patients who were ER+ and progesterone receptor (PR)+ compared to those with ER- and PR-. In the Saudi females, rs1801320 did not show an association with risk of breast cancer. Taken together, the results suggest that RAD51 rs1801321 polymorphism may be involved in the etiology of breast cancer in the Saudi females; however, further studies are necessary to confirm this relation.
\end{abstract}

Keywords: RAD51, breast cancer, Saudi Arabia, single nucleotide polymorphism

\section{Introduction}

DNA damage may be caused by ultraviolet and ionizing radiations, environmental chemical agents, and reactive oxidative stresses resulting from various metabolic processes occurring normally in the body. ${ }^{1}$ A variety of mutagens in the environment also cause DNA damage, DNA adducts formation, and breaks in DNA strand. ${ }^{2}$ If left uncorrected, damages to DNA accumulate in cells and may lead to dysregulation of the cell cycle, autonomous and uncontrolled growth and development of such invasive mechanisms, which finally lead to the development of cancer. ${ }^{3}$ Several mechanisms have been developed by mammalian cells, specific for each type of damage, to repair the damaged DNA, in an attempt to maintain the integrity of the genome. Moreover, the genes responsible for the gene products involved in the repair mechanisms are contemplated as possible cancer susceptibility genes. ${ }^{4,5}$ The proper functioning of the DNA repair mechanisms is essential as this is a means to preserve genomic stability 
and functionality. Several studies have reported that highly penetrant mutations in these genes are possible causative factors in some of the familial cancer syndromes, while a number of low-penetrant single-nucleotide polymorphisms (SNPs) may predispose to the development of different forms of cancers, including breast cancer. ${ }^{6-8}$

Several molecular epidemiological studies have been performed in an attempt to evaluate the relation between polymorphic sites in the different DNA repair genes and different types of cancer risk in diverse populations. ${ }^{9,10}$ Among the genes, $R A D 51$ has been considered as a possible candidate due to its central involvement in the repair of double-strand DNA breaks by facilitating homologous pairing and strand exchanges in recombinatory structures. ${ }^{11-13}$ The $R A D 51$ gene, a highly conserved gene found in most eukaryotes, from yeast to humans, encodes for the RAD51 protein. The RAD51 family members are homologous to the bacterial Rec $\mathrm{A}$ and yeast $R A D 51$. The RAD51 protein is involved in homologous recombination and interacts directly with X-ray repair cross-complementing proteins 2 and 3 (XRCC2, XRCC3), Breast cancer genes 1 and 2 (BRCA1, BRCA2), and so on to form a complex that is essential during double-strand break repair and DNA cross-links (especially, XRCC2 and XRCC3) and hence plays an essential role in the maintenance of chromosome stability. Several studies have reported that the RAD51 protein exhibits reduced expression in breast cancers, both sporadic and familial, and based on these findings, it was hypothesized that the genetic mutations and polymorphisms within the RAD51 gene may contribute to the differences observed between individuals with regard to susceptibility to breast cancer tumorigenesis. $2,8,14,15$ Several population-based studies have been conducted, but, interestingly, results from different studies present contradictory results in different populations. ${ }^{15-19}$

To the best of our knowledge, since no studies have been reported on the association between SNPs in RAD51 and susceptibility to breast cancer development in Saudi females, we initiated this study on three SNPs in RAD51 [rs1801320 $(\mathrm{G}>\mathrm{C}), \mathrm{rs} 1801321(\mathrm{G}>\mathrm{T})$, and $\mathrm{rs} 2619681(\mathrm{C}>\mathrm{T})]$ in a group of Saudi breast cancer patients and compared the results with normal healthy controls. This article presents our findings and shows a close relation between the susceptibility to breast cancer development and some of the polymorphic sites in RAD51.

\section{Subjects and methods The study population}

The Saudi population investigated during this study comprised 96 females (median age $=48$ years) suffering from breast cancer who attended the outpatient clinics of the clinical coinvestigators (HAK) at King Fahad Medical City Hospital, Riyadh, Saudi Arabia, and 96 age- and sexmatched normal healthy controls who also attended King Fahad Medical City Hospital for minor illnesses and were recruited following diagnostic exclusion of cancer or history of cancer and cancer-related diseases. The patient and control populations were from Saudi Arabian ethnicity, and the majority (86/96) had a sporadic onset. Physical examination was carried out, and demographic data, age at diagnosis, tumor grade, and receptor status of estrogen receptor (ER), progesterone receptor (PR), and human epidermal growth factor receptor 2 (HER2) were recorded. The Institutional Review Board of King Khalid Hospital approved the study (IRB No. 15-089E); written informed consent was obtained from all individuals included in the study.

\section{DNA extraction protocol}

Approximately $3 \mathrm{~mL}$ blood samples were collected by venipuncture in vacutainer tubes containing ethylenediaminetetraacetic acid from all subjects enrolled in the study and were stored at $4^{\circ} \mathrm{C}$ until required for DNA extraction. Genomic DNA was extracted using QIAmp DNA Blood Mini Kit (Qiagen N.V., Venlo, the Netherlands), and the manufacturer's instructions were followed. After extraction of the DNA, each sample was subjected to purification, and the DNA was spectrophotometrically quantitated using the NanoDrop 8000 (Thermo Fisher Scientific, Waltham, MA, USA). Purity was determined using the standard $A_{260} / A_{280}$ and $A_{260} / A_{230}$ ratios, and the DNA was stored until required for genotyping.

\section{Genotyping}

Three SNPs in RAD51 were selected and genotyped. Two SNPs [rs1801321 (G>T) and rs2619681 (C>T)] were analyzed using TaqMan allelic discrimination assay and one, rs1801320 (G>C), was analyzed by polymerase chain reaction (PCR)-restriction fragment length polymorphism (RFLP) (designed using PRIMER3). RFLP primers were validated by sequencing the PCR products. For TaqMan genotyping assay, the primers and probe mixture were purchased directly through the assays-on-demand service of Thermo Fisher Scientific. During analysis, $20 \mathrm{ng}$ of DNA per reaction was used with $5.6 \mu \mathrm{L}$ of $2 \times$ Universal Master Mix and $200 \mathrm{nM}$ primers (Thermo Fisher Scientific). All genotypes were determined by endpoint reading on an ABI 7500 real-time PCR instrument using the Sequence Detection Software (Thermo Fisher Scientific). Negative controls were 
rs1801321 (172G>T variant) in RAD51

Allele discrimination plot

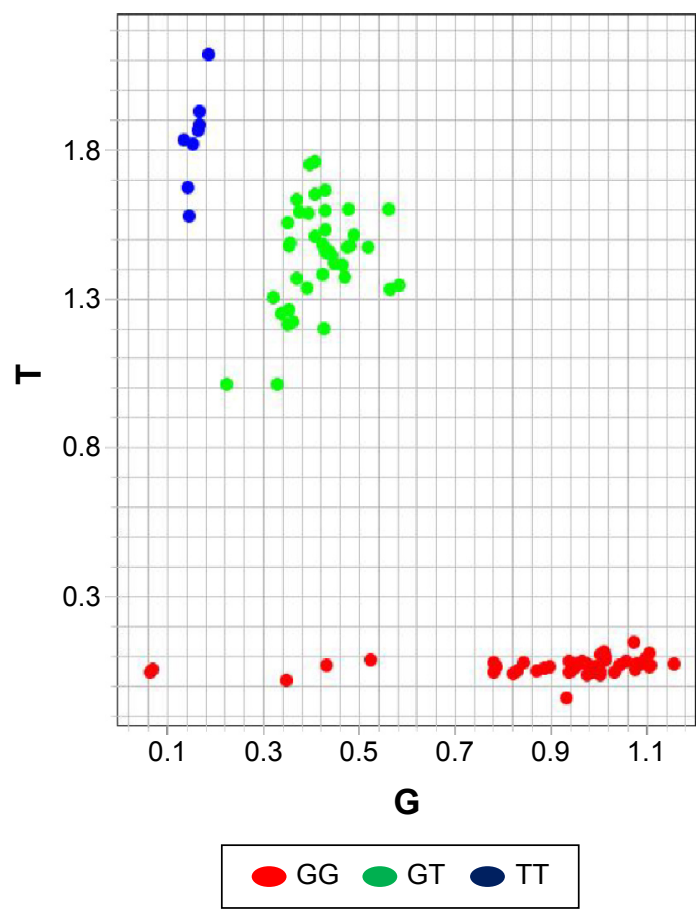

rs2619681 (C>T variant) in RAD51

Allele discrimination plot

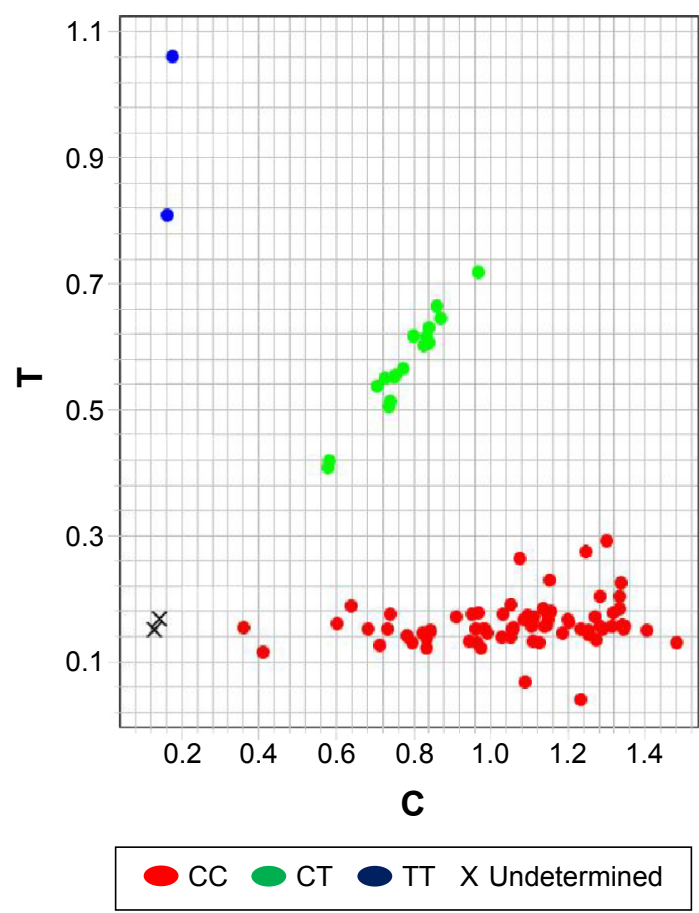

Figure I Detection of the rs I80I32I (G>T) and rs26I968I (C>T) genotypes in RAD5 I using TaqMan genotyping assay.

used in RFLP and TaqMan assay experiments to reduce experimental errors. Figure 1 presents the results of genotyping using the TaqMan genotyping kit.

For rs1801320 (135G $>$ C) genotyping, the primers used and the fragments obtained after restriction of the PCR product with restriction endonuclease BstNI are presented in Table 1. A total of $2.5 \mu \mathrm{L}$ of $10 \times \mathrm{PCR}$ buffer (Qiagen), $2 \mu \mathrm{L}$ of $2.5 \mathrm{mM}$ deoxyribonucleotide triphosphate (dNTPs) (Promega Corporation, Fitchburg, WI, USA), $1 \mu \mathrm{L}$ from each of primers $\mathrm{F}$ and $\mathrm{R}$ ( $5 \mathrm{pmol}), 2 \mu \mathrm{L}$ of DNA ( $20 \mathrm{ng} / \mu \mathrm{L}$ ), and $0.2 \mu \mathrm{L}$ of hot start Taq polymerase (Qiagen) were mixed, and the volume was made up to $25 \mu \mathrm{L}$ by deionized RNase- and DNase-free water. Cycling parameters presented in Qiagen handbook were followed: initial activation was carried out at $95^{\circ} \mathrm{C}$ for 15 minutes, followed by 35 cycles of denaturation at $95^{\circ} \mathrm{C}$ for 40 seconds, annealing at $61.8^{\circ} \mathrm{C}$ for 40 seconds, and elongation at $72^{\circ} \mathrm{C}$ for 40 seconds and then the final elongation step at $72^{\circ} \mathrm{C}$ for 10 minutes. After amplification, the PCR product was subjected to agarose gel electrophoresis to confirm that the amplification had taken place and a $600 \mathrm{bp}$ fragment was obtained. The PCR products were digested with BstNI for 2 hours at $60^{\circ} \mathrm{C}$, and the fragments obtained were subjected to electrophoresis in 3\% agarose gel. Ethidium bromide was incorporated in the gel for visualization of the DNA fragments under ultraviolet light. For each genotype of the tested SNP, the sizes of the fragments obtained are presented in Table 1. Figure 2 presents an electrophoretogram of the fragments following agarose gel electrophoresis.

As a quality control measure for verification of genotyping procedure for rs 1901320 using PCR-RFLP, 5\% of the

Table I Primers used for amplification of RAD5I SNP ( $r$ I80 I320, G $>$ C) and fragments obtained after restriction with BstNI for the three genotypes

\begin{tabular}{|c|c|c|c|c|c|}
\hline $\begin{array}{l}\text { RAD5I } \\
(\text { rs }|80| 320)\end{array}$ & $5^{\prime}-3^{\prime}$ primer sequences & Tm & $\begin{array}{l}\text { Product } \\
\text { size (bp) }\end{array}$ & RE used & $\begin{array}{l}\text { Size (bp) of the fragments } \\
\text { obtained after RE treatment }\end{array}$ \\
\hline RAD5 I F & AAGGGAAGAGGGCAGTCTGT & $61.8^{\circ} \mathrm{C}$ & 600 & BstNI & GG: $136,176,161,127$ bp \\
\hline RAD5 I R & CACAAGTGGACCTCAGTCT & & & & $\begin{array}{l}\text { GC: } 136 / 127,337,176,161 \text { bp } \\
\text { CC: } 136,337,127 \text { bp }\end{array}$ \\
\hline
\end{tabular}

Abbreviations: SNP, single-nucleotide polymorphism; RE, restriction endonuclease; Tm, melting temperature. 


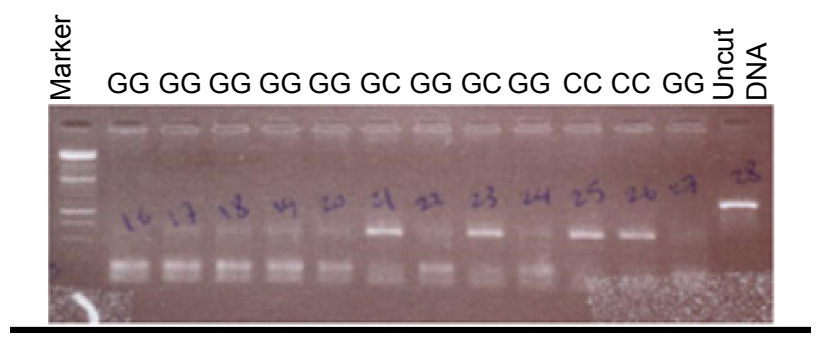

Figure 2 Agarose gel electrophoresis of rs|80|320 in RAD5I I35G $>C$ variant after digestion with BstNI (the genotype is shown at the top of the electrophoretogram).

samples genotyped were randomly selected and subjected to sequencing analysis. The results of the three genotypes are presented in Figure 3 and were reproducible without any discrepancies.

\section{Statistical analysis}

Each sample was assigned its genotype. The number of each genotype was obtained manually, and the frequencies of the genotypes and alleles were manually computed. Any deviation from Hardy-Weinberg equilibrium was checked using the website http://ihg2.helmholtz-muenchen.de/cgi-bin/hw/ hwal.pl. The frequencies of the genotypes and alleles in the cases and controls were calculated using the chi-square test and unadjusted odds ratios (ORs), and 95\% confidence intervals (CIs) were calculated by Fisher's exact test (twotailed). Statistical analysis was carried out using SPSS 21 for Windows. A $P$-value of $\leq 0.05$ was considered statistically significant.

\section{Results}

Table 2 presents the demographic data and receptor status of the breast cancer patients investigated during this study. The frequency of each genotype and its alleles was calculated in the total patients group and in the patients grouped according to the age of diagnosis, tumor status, and receptor status. The genotype and allele frequencies of the three SNPs investigated in the breast cancer patients and the controls are presented in Table 3. For rs $1801321 \mathrm{G}>\mathrm{T}$, the majority of breast cancer patients were homozygous for the wildtype $\mathrm{G}$ allele and a strong relation was observed between rs 1801321 polymorphism and breast cancer susceptibility. The GG genotype and $\mathrm{G}$ allele were strongly associated with an elevated risk of breast cancer in the Saudi population with $P<0.0001$. The mutant T, on the other hand, seems to provide protection against breast cancer development since the frequency of the TT and GT genotype was significantly lower in the patients compared to the controls $(P<0.0001)$. For the rs1801320 $\mathrm{G}>\mathrm{C}$, no significant differences were found in the genotype and allele frequencies for the $\mathrm{C}$ and $\mathrm{G}$ alleles in breast cancer patients and normal controls. For rs2619681 (C>T), the homozygous CC genotype occurred at a significantly higher frequency in the breast cancer patients $(P<0.05)$. When the patients were compared to the control group, the allele frequency showed statistically significant difference $(P<0.05)$ and the OR for the $\mathrm{T}$ allele was 0.487 . Since the frequency of the $\mathrm{T}$ allele was higher in the control group, it showed a protective effect against cancer development.

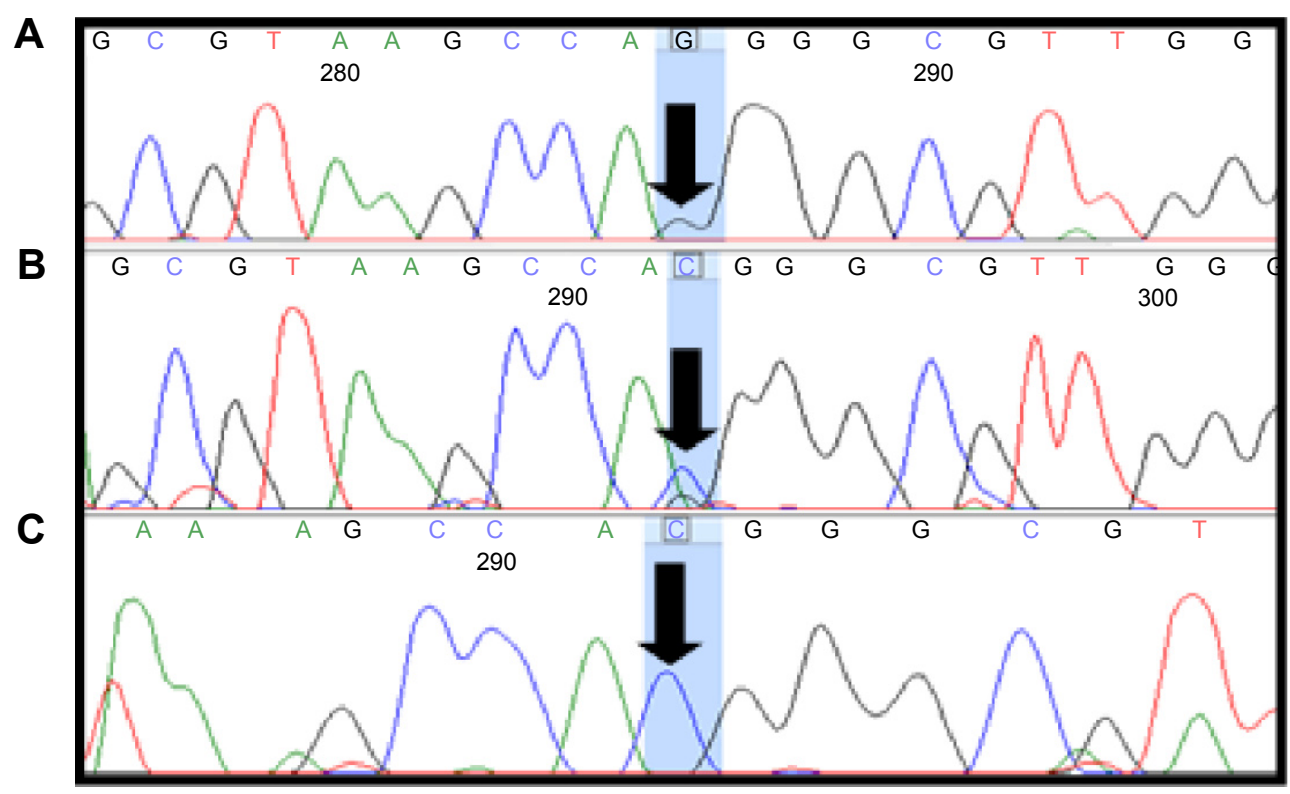

Figure 3 Sequence of the (A) wild-type allele (G), (B) heterozygous allele (GC), and (C) homozygous mutant allele (C) of rs I 80 I 320 in RAD5 I (I35G >C variant). 
Table 2 Demographic data and receptor status of the patients with breast cancer

\begin{tabular}{llllll}
\hline $\begin{array}{l}\text { Patients } \\
\text { with cancer }\end{array}$ & $\begin{array}{l}\text { Average } \\
\text { age (years) }\end{array}$ & $\begin{array}{l}\text { Tumor grade } \\
\text { (number of patients) }\end{array}$ & $\begin{array}{l}\text { ER status } \\
\text { (number of patients) }\end{array}$ & $\begin{array}{l}\text { PR status } \\
\text { (number of patients) }\end{array}$ & $\begin{array}{l}\text { HER2 status } \\
\text { (number of patients) }\end{array}$ \\
\hline 96 & $<40=27$ & $\mathrm{I}=\mathrm{I}$ & $\mathrm{ER}+=55$ & $\mathrm{PR}+=56$ & HER2+=4I \\
& $>40=7 \mathrm{I}$ & $\mathrm{II}=49$ & $\mathrm{ER}-=45$ & $\mathrm{PR}-=44$ & HER2-=57 \\
& & & & \\
& $\mathrm{II}=37$ & & &
\end{tabular}

Abbreviations: ER, estrogen receptor; PR, progesterone receptor; HER2, human epidermal growth factor receptor 2.

The cancer patients were grouped on the basis of the age of diagnosis, tumor stage, and the ER, PR, and HER2 statuses. The genotype frequencies were calculated, the allele frequencies were obtained from the different groups, and the results were compared. Table 4 summarizes the results obtained. There was no significant difference in the genotype and allele frequencies of the three SNPs in patients who had an early onset of cancer compared to those with a late onset. The frequencies of the three SNPs also did not differ in patients with different tumor grades and HER 2 status ( + or - ). However, the frequency of rs $1801320(135 \mathrm{G}>\mathrm{C})$ differed in the ER+ and ER-, where the CC genotype was significantly higher in the ER- breast cancer females. Finally, the allele frequency of $\mathrm{C}$ allele of rs2619681 C $>\mathrm{T}$ was significantly higher in the ER+ and PR+ breast cancer patients compared to that of the ER- and PR- patients. The results of rs 2619681 $\mathrm{C}>\mathrm{T}$ in the $\mathrm{PR}+$ and $\mathrm{ER}+$ breast cancer patients in comparison to those of the PR- and ER- breast cancer patients are presented in Table 5.

\section{Discussion}

Research conducted over the last few decades has made it apparent that the pathways involved in the repair of DNA are continuously monitoring chromosomes in an attempt to correct damages caused by endogenous mutagens and exogenous agents, such as ultraviolet light or cigarette smoke.

Table 3 Genotype and allele frequencies of studied SNPs in breast cancer patients and controls

\begin{tabular}{|c|c|c|c|c|c|c|}
\hline Genotype & Cases & Controls & OR & $95 \% \mathrm{Cl}$ & $x^{2}$ & $P$-value \\
\hline \multicolumn{7}{|c|}{ RAD5/ rs $180 \mid 321 \mathrm{G}>\mathrm{T}$} \\
\hline \multicolumn{7}{|c|}{ Genotype frequency } \\
\hline GG & 48 (50\%) & 0 & Ref & & & \\
\hline GT & $40(41.666 \%)$ & $45(46.875 \%)$ & 0.009 & $0.00 I-0.154$ & 38.41 & $<0.000$ I \\
\hline TT & $8(8.333 \%)$ & 51 (53.125\%) & 0.002 & $0.000-0.030$ & 79.28 & $<0.000$ I \\
\hline $\mathrm{GT}+\mathrm{TT}$ & $48(50 \%)$ & $96(100 \%)$ & 0.005 & $0.000-0.086$ & 64.00 & $<0.0001$ \\
\hline \multicolumn{7}{|c|}{ Allele frequency } \\
\hline G & I $36(0.708)$ & $45(0.234)$ & Ref & $0.080-0.199$ & 86.54 & $<0.0001$ \\
\hline $\mathrm{T}$ & $56(0.291)$ & $147(0.765)$ & 0.126 & & & \\
\hline \multicolumn{7}{|c|}{ RAD5/ rsI80I320 G $>C$} \\
\hline \multicolumn{7}{|c|}{ Genotype frequency } \\
\hline GG & 59 (59\%) & $60(60 \%)$ & Ref & & & \\
\hline GC & 31 (3।\%) & 31 (3l\%) & 1.017 & $0.550-1.879$ & 0.00 & 0.957 \\
\hline $\mathrm{CC}$ & $10(10 \%)$ & $9(9 \%)$ & 1.130 & $0.429-2.980$ & 0.06 & 0.804 \\
\hline $\mathrm{GC}+\mathrm{CC}$ & $4 \mid(4 I \%)$ & 40 (40\%) & 1.042 & $0.593-1.833$ & 0.02 & 0.885 \\
\hline \multicolumn{7}{|c|}{ Allele frequency } \\
\hline G & $149(0.745)$ & I5I (0.755) & Ref & $0.67 I-1.659$ & 0.05 & 0.817 \\
\hline C & $5 \mathrm{I}(0.255)$ & $49(0.245)$ & 1.055 & & & \\
\hline \multicolumn{7}{|c|}{ RAD5 I rs261968I C>T } \\
\hline \multicolumn{7}{|c|}{ Genotype frequency } \\
\hline $\mathrm{CC}$ & 75 (79.787\%) & $63(66.315 \%)$ & Ref & & & \\
\hline $\mathrm{CT}$ & 17 (I8.085\%) & $25(26.315 \%)$ & $0.57 \mid$ & $0.283-1.152$ & 2.48 & 0.11533 \\
\hline TT & $2(2.127 \%)$ & $7(7.368 \%)$ & 0.240 & $0.048-1.197$ & 3.50 & 0.06152 \\
\hline $\mathrm{CT}+\mathrm{TT}$ & $19(20.21 \%)$ & $32(33.68 \%)$ & 0.499 & $0.258-0.964$ & 4.35 & 0.03696 \\
\hline \multicolumn{7}{|c|}{ Allele frequency } \\
\hline C & $167(0.888)$ & I5I (0.794) & Ref & $0.274-0.865$ & 6.19 & 0.01281 \\
\hline $\mathrm{T}$ & $21(0.111)$ & $39(0.205)$ & 0.487 & & & \\
\hline
\end{tabular}

Abbreviations: SNP, single-nucleotide polymorphism; OR, odds ratio; Cl, confidence interval; Ref, reference. 
Table 4 Comparison of the genotype and allele frequencies of the three SNPs in breast cancer patients grouped on the basis of age of diagnosis, tumor grade, ER, PR, and HER2 statuses

\begin{tabular}{llll}
\hline Parameter & Group & Group & Significance \\
\hline RAD5I rs I80I32I $(I 72 G>T)$ & & \\
Age at diagnosis & $>40$ years & $<40$ years & NS \\
ER & + & - & NS \\
PR & + & - & NS \\
HER2 & + & - & NS \\
Tumor grade & II & III & NS \\
RAD5I rs I80I320 $($ I35G $>$ C) & & \\
Age at diagnosis & $>40$ years & $<40$ years & NS \\
ER & + & $-\uparrow C C$ & $<0.05$ \\
PR & + & - & NS \\
HER2 & + & - & NS \\
Tumor grade & II & III & NS \\
RAD5I rs26I968I C $>$ T & & \\
Age at diagnosis & $>40$ years & $<40$ years & NS \\
ER & $+\uparrow C$ & - & $<0.05$ \\
PR & $+\uparrow C$ & - & $<0.05$ \\
HER2 & + & - & NS \\
Tumor grade & II & III & NS \\
\hline
\end{tabular}

Abbreviations: SNP, single-nucleotide polymorphism; ER, estrogen receptor; PR, progesterone receptor; HER2, human epidermal growth factor receptor 2; NS, not significant.

By repairing these damages, these pathways play a critical role in protecting against genetic mutations. ${ }^{3,4}$ These pathways are hence responsible for conserving the stability and integrity of the human genome. ${ }^{3-5}$ Extensive genetic studies have been carried out on different DNA repair genes to identify possible loci predisposing to increased susceptibility to different forms of cancer., ${ }^{9,16,20-23}$ Defects in DNA repair pathways may alter the capacity of the cell to repair damaged
DNA, leading to an accumulation of DNA damages. This may be followed by unregulated cell growth and irregularities of programmed cell death and may account, in part, for the development of cancer. ${ }^{5}$

Double-strand break damage in the DNA is considered as the most dangerous lesion as it may lead to cell death and may constitute a grave threat to viability of the cells and stability of the genome. Cell survival may be endangered since cell cycle progression may be permanently arrested. ${ }^{24}$ Any defects in these repair mechanisms may result in the accumulation of chromosomal aberrations, which may increase the susceptibility to develop cancer. $5,9,25$ The two pathways actively involved in the repair of double-strand breaks are nonhomologous end-joining and homologous recombination. Both these pathways have been investigated extensively, and several polymorphisms have been highlighted in the enzymes and proteins involved in these pathways. ${ }^{26-28}$

Among the many genes investigated, RAD51 has attracted extensive attention. It is one of the key proteins for homologous recombination and plays a crucial role in homologous recombination repair of DNA double-strand breaks. ${ }^{29}$ The main function of RAD51 is in DNA repair, where it forms nucleoprotein filaments on single-stranded DNA, induces homologous pairing, and mediates strand exchange reactions between single- and double-stranded DNA. ${ }^{30}$ The gene for RAD51 (RAD51 gene) is located on chromosome 15q15.1 in humans, and RAD51 gene polymorphisms have attracted widespread attention. Among the many polymorphic sites, two sites have been extensively investigated. These are

Table 5 Genotype and allele frequency of RAD5I rs261968I C > T in patients with different PR and ER statuses

\begin{tabular}{|c|c|c|c|c|c|c|}
\hline \multirow{2}{*}{$\begin{array}{l}\text { RAD5I } \\
\text { rs26I968I C }>\text { T } \\
\end{array}$} & & & \multirow[t]{2}{*}{ OR } & \multirow[t]{3}{*}{$\mathrm{Cl}$} & \multirow[t]{2}{*}{$\chi^{2}$ (P-value) } & \multirow[t]{2}{*}{$P$-value } \\
\hline & & & & & & \\
\hline & PR+, N (\%) & PR-, N (\%) & & & & \\
\hline \multicolumn{7}{|c|}{ Genotype frequency } \\
\hline $\mathrm{CC}$ & 47 (87\%) & $28(70 \%)$ & 2.88 & $1.01-8.17$ & 4.136 & 0.041 \\
\hline $\mathrm{CT}$ & $7(13 \%)$ & $10(25 \%)$ & 0.45 & $0.15-1.30$ & 2.247 & 0.133 \\
\hline TT & 0 & $2(5 \%)$ & & & & \\
\hline \multicolumn{7}{|l|}{ Allele frequency } \\
\hline C & $101(0.935)$ & $66(0.825)$ & 3.06 & $0.17-7.98$ & 5.623 & 0.017 \\
\hline $\mathrm{T}$ & $7(0.064)$ & $14(0.175)$ & 0.33 & $0.13-0.85$ & 5.623 & 0.017 \\
\hline \multirow[t]{2}{*}{ Total number } & 108 & 80 & & & & \\
\hline & ER+, N (\%) & ER-, N (\%) & & & & \\
\hline \multicolumn{7}{|c|}{ Genotype frequency } \\
\hline $\mathrm{CC}$ & $46(86.8 \%)$ & $29(70.7 \%)$ & 2.72 & $0.96-7.71$ & 3.697 & 0.054 \\
\hline $\mathrm{CT}$ & $7(13.2 \%)$ & $10(24.5 \%)$ & 0.47 & $0.16-1.37$ & 1.951 & 0.162 \\
\hline $\mathrm{TT}$ & 0 & $2(4.8 \%)$ & & & & \\
\hline \multicolumn{7}{|l|}{ Allele frequency } \\
\hline C & $99(0.933)$ & $68(0.829)$ & 2.91 & I.12-7.59 & 5.107 & 0.023 \\
\hline $\mathrm{T}$ & $7(0.066)$ & $14(0.170)$ & 0.34 & $0.13-0.90$ & 5.107 & 0.023 \\
\hline Total number & 106 & 82 & & & & \\
\hline
\end{tabular}

Abbreviations: PR, progesterone receptor; ER, estrogen receptor; OR, odds ratio; $\mathrm{Cl}$, confidence interval. 
Table 6 Frequency of $\mathrm{rs}$ 180132I I72G>T in RAD5I in different types of cancer in different populations

\begin{tabular}{lllll}
\hline Cancer types & Population & No of patients studied & Effect & References \\
\hline RAD5I rs $I 80 I 32 I(I 72 G>T)$ & & & No association & 39 \\
Ovarian cancer & Poland & Patients $=210$ & No association & 40 \\
Ovarian cancer & Polish & Patients $=120$, controls $=120$ & No association & $4 I$ \\
Breast cancer & Caucasian & Patients $=289$, controls $=548$ & No association & 42 \\
Colorectal cancer & Poland & Patients $=320$, controls $=320$ & No association & 43 \\
Endometrial cancer & Polish & Patients $=240$, controls $=240$ & \\
\hline
\end{tabular}

rs 1801320, a $\mathrm{G}$ to $\mathrm{C}$ transversion at the position +135 , and rs1801321, a G to $\mathrm{T}$ transversion at the position 172. Both these sites are located in the $5^{\prime}$ untranslated region and are believed to have functional relevance. They are shown to affect stability of mRNA or translational efficiency and lead to altered level and function of the polypeptide product (RAD51 protein), thus influencing the DNA repair capacity to some extent. ${ }^{31,32}$ Reduced expression of the RAD51 protein is reported in both sporadic and familial breast cancer patients, and based on these findings, it has been hypothesized that the genetic variation within the RAD51 gene may contribute to carcinogenesis. ${ }^{7,8,17,19}$ It is suggested that these findings also explain observed interindividual differences with regard to breast cancer susceptibility.

Extensive molecular epidemiological studies on the frequency of these polymorphisms in cancer patients and healthy controls in different populations have revealed contradictory findings. With regard to both rs $1801320135 \mathrm{G}>\mathrm{C}$ and rs $1801321172 \mathrm{G}>\mathrm{T}$, studies have shown a close association between this SNP and risk of different cancers. A few of the studies are summarized in Tables 6 and 7. In breast cancer patients, the studies also revealed contradictory results and showed both association and no association. ${ }^{7,8,18}$ This led to meta-analyses of the previous studies by different groups of researchers, and again, there were contradictions. ${ }^{19}$ These differences to some extent were related to the type of breast cancer, ie, sporadic or familial, and were due to different BRCA1 and 2 statuses of the patients. Since results of the previous studies were inconclusive, a recent extensive meta-analysis was conducted to determine the associations between $R A D 51$ gene polymorphisms (rs1801320 135G $>C$ and rs $1801321172 \mathrm{G}>\mathrm{T}$ ) and risk of cancer. ${ }^{33}$ This metaanalysis was performed on 54 published case-control studies. Among them, 42 studies with 19,142 cases and 20,363 controls were for rs $1801320135 \mathrm{G}>\mathrm{C}$ polymorphism and 12 studies with 6,646 cases and 6,783 controls for rs 1801321 $172 \mathrm{G}>\mathrm{T}$ polymorphism. The overall results showed that for $135 \mathrm{G}>\mathrm{C}$ (rs1801320) polymorphism, the pooled results indicate significantly increased risk for overall cancers, especially breast cancer, while for rs1801321 172G $>$ T (rs1801321) polymorphism, this meta-analysis showed a decreased cancer risk in head and neck cancers.

Despite the conclusive results of the comprehensive metaanalyses, our study presents another contradictory finding in Saudi breast cancer patients. For rs1801320 135G $>$ C, no association was observed between the genotype and allele frequencies in the breast cancer patients and the normal controls. When the breast cancer patients were grouped

Table 7 Frequency of rs I80I320 I35G >C in RAD5I in different types of cancer in different populations

\begin{tabular}{|c|c|c|c|c|}
\hline Cancer types & Population & No of patients studied & Effect & References \\
\hline Larynx cancer & Polish & Patients $=253$ & Association & 44 \\
\hline Breast cancer & Polish & Patients $=790$ & Association & 45 \\
\hline Endometrial cancer & Polish & Patients $=230$ & Association & 46 \\
\hline Sporadic breast cancer & Polish & Patients $=700$, controls $=708$ & Association & 47 \\
\hline Ovarian cancer & Poland & Patients $=210$ & Association & 39 \\
\hline Breast cancer & Serbian & $\begin{array}{l}\text { Patients }(B R C A-) \text { with history of } \\
\text { cancer }=48 \text {, patients without history } \\
\text { of cancer }=107 \text {, control group }=1 \mid 4\end{array}$ & Association & 48 \\
\hline Esophageal cancer & Chinese & Patients $=\mid 23$, controls $=6 \mathrm{I}$ & Association & 7 \\
\hline Ovarian cancer & Polish & Patients $=120$, controls $=120$ & Association & 40 \\
\hline Breast cancer & Iranian & Patients $=294$, controls $=315$ & Association & 8 \\
\hline Endometrial cancer & Polish & Patients $=240$, controls $=240$ & Association & 43 \\
\hline Acute myeloid leukemia & Chinese & Patients $=806$, controls $=704$ & Association & 49 \\
\hline Colorectal cancer & Poland & Patients $=320$, controls $=320$ & Association & 42 \\
\hline
\end{tabular}

Abbreviation: BRCA, breast cancer. 
according to the age of diagnosis, tumor grade, and ER, PR, and HER2 statuses of the patients, and the frequency of rs1801320 was compared in the two groups, no significant differences were identified except in those with ER+ and ERphenotypes, where the homozygous CC genotype occurred at a higher frequency in the individuals who were ER- and the difference compared to the results in ER+ was statistically significant. On the other hand, our results in Saudis show a highly significant association of rs1801321 172G $>$ T with breast cancer, where the $\mathrm{G}$ allele was highly predisposing to breast cancer risk and almost $50 \%$ of the breast cancer patients had the GG genotype, $41.7 \%$ had the GT genotype, and only $8.3 \%$ had the TT genotype. On the other hand, none of the control group had the GG genotype, 53.13\% had the TT genotype, and $46.88 \%$ had the GT genotype. The T allele was highly protective $(\mathrm{OR}=0.126 ; 95 \% \mathrm{CI}=0.080-0.199$; $P<0.0001)$.

The results of this study suggest a relation between RAD51 and susceptibility to develop breast cancer. Interestingly, a polymorphism, a $\mathrm{G}>\mathrm{T}$ transversion in the $5^{\prime}$ untranslated region, which probably affects the stability of mRNA of RAD51, leading to an increase in the rate of its posttranscriptional expression and hence an increase in the level of RAD51 protein decreases the risk of breast cancer. This well known affect is an interaction between several proteins, including BRCA1 and BRCA2, which are the two key players during homologous recombination. Hence, RAD51 functions as a tumor suppressor gene. This hypothesis needs confirmation, and further detailed investigations are required to work out the mechanism.

As far as rs1801320 was concerned, the results in Saudis are in agreement with the results reported from USA, Poland, and other populations, ${ }^{6,17,34-38}$ and the results of the meta-analysis that did not find any association between this SNP and breast cancer.

\section{Acknowledgment}

The authors extend their appreciation to the Deanship of Scientific Research at King Saud University for funding this work through research group project RGPVPP-081.

\section{Disclosure}

The authors report no conflicts of interest in this work.

\section{References}

1. De Bont R, van Larebeke N. Endogenous DNA damage in humans: a review of quantitative data. Mutagenesis. 2004;19(3):169-185.

2. Barnes DE. DNA damage: air-breaks? Curr Biol. 2002;12(7):R262-R264.
3. Chen C, editor. New Research Directions in DNA Repair. Croatia: InTech Publishers; 2013.

4. Bernstein B, Prasad AR, Nfonsam V, et al. DNA damage, DNA repair and cancer. In: Chen C, editor. New Research Directions in DNA Repair. Croatia: InTech, Publishers; 2013;16:413-465.

5. Dixon K, Kopras E. Genetic alterations and DNA repair in human carcinogenesis. Semin Cancer Biol. 2004;14(6):441-448.

6. Dufloth RM, Costa S, Schmitt F, et al. DNA repair gene polymorphisms and susceptibility to familial breast cancer in a group of patients from Campinas, Brazil. Genet Mol Res. 2005;4(4):771-782.

7. Fan XJ, Ren PL, Lu ZJ, et al. The study of esophageal cancer risk associated with polymorphisms of DNA damage repair genes XRCC4 and RAD51. Sichuan Da Xue Xue Bao Yi Xue Ban. 2013;44(4):568-572.

8. Hosseini M, Houshmand M, Ebrahimi A. RAD51 polymorphisms and breast cancer risk. Mol Biol Rep. 2013;40(1):665-668.

9. Berwick M, Vineis P. Markers of DNA repair and susceptibility to cancer in humans: an epidemiologic review. J Natl Cancer Inst. 2000;92: 874-897.

10. Goode EL, Ulrich CM, Potter JD. Polymorphisms in DNA repair genes and associations with cancer risk. Cancer Epidemiol Biomarkers Prev. 2002;11:1513-1530.

11. Benson FE, Baumann P, West SC. Synergistic actions of Rad51 and Rad52 in recombination and DNA repair. Nature. 1998;391(6665):401-404.

12. Arnaudeau C, Lundin C, Helleday T. DNA double-strand breaks associated with replication forks are predominantly repaired by homologous recombination involving an exchange mechanism in mammalian cells. J Mol Biol. 2001;307(5):1235-1245.

13. van den Bosch M, Lohman PH, Pastink A. DNA double-strand break repair by homologous recombination. Biol Chem. 2002;383(6):873-892.

14. Vral A, Willems P, Claes K, et al. Combined effect of polymorphisms in Rad51 and XRCC3 on breast cancer risk and chromosomal radio sensitivity. Mol Med Rep. 2011;4(5):901-912.

15. Khanna KK, Jackson SP. DNA double-strand breaks: signaling, repair and the cancer connection. Nat Genet. 2001;27(3):247-254.

16. Ricceri F, Matullo G, Vineis P. Is there evidence of involvement of DNA repair polymorphisms in human cancer? Mutat Res. 2012;736: 117-121.

17. Blasiak J, Przybyłowska K, Czechowska A, et al. Analysis of the G/C polymorphism in the $5^{\prime}$-untranslated region of the $R A D 51$ gene in breast cancer. Acta Biochim Pol. 2003;50(1):249-253.

18. Brooks J, Shore RE, Zeleniuch-Jacquotte A, et al. Polymorphisms in $R A D 51, X R C C 2$, and $X R C C 3$ are not related to breast cancer risk. Cancer Epidemiol Biomark Prev. 2008;17(4):1016-1019.

19. Gao L, Pan X, Li L, et al. RAD51 135G/C polymorphism and breast cancer risk: a meta-analysis from 21 studies. Breast Cancer Res Treat. 2011;125(3):827-835.

20. Butkiewicz D, Rusin M, Enewold L, et al. Genetic polymorphisms in DNA repair genes and risk of lung cancer. Carcinogenesis. 2001; 22(4):593-597.

21. Krajinovic M, Labuda D, Mathonnet G, et al. Polymorphisms in genes encoding drugs and xenobiotic metabolizing enzymes, DNA repair enzymes, and response to treatment of childhood acute lymphoblastic leukemia. Clin Cancer Res. 2002;8:802-810.

22. $\mathrm{Hu} \mathrm{Z}, \mathrm{Ma} \mathrm{H}$, Chen F, et al. XRCC1 polymorphisms and cancer risk: a meta-analysis of 38 case-control studies. Cancer Epidemiol Biomarkers Prev. 2005;14:1810-1818.

23. Manuguerra M, Saletta F, Karagas MR, et al. XRCC3 and XPD/ERCC2 single nucleotide polymorphisms and the risk of cancer: a HuGE review. Am J Epidemiol. 2006;164:297-302.

24. Suwaki N, Klare K, Tarsounas M. RAD51 paralogs: roles in DNA damage signalling, recombinational repair and tumorigenesis. Semin Cell Dev Biol. 2011;22:898-905.

25. Wood RD, Mitchell M, Lindahl T. Human DNA repair genes. Mutat Res. 2005;577:275-283.

26. Lisby M, Rothstein R. Choreography of recombination proteins during the DNA damage response. DNA Repair (Amst). 2009;8:1068-1076. 
27. Yano K, Morotomi-Yano K, Adachi N, et al. Molecular mechanism of protein assembly on DNA double-strand breaks in the non-homologous end-joining pathway. J Radiat Res. 2009;50:97-108.

28. West SC. Molecular views of recombination proteins and their control. Nat Rev Mol Cell Biol. 2003;4:435-445.

29. Richardson C. RAD51, genomic stability, and tumorigenesis. Cancer Lett. 2005;218:127-139.

30. Vispe S, Defais M. Mammalian Rad51 protein: a RecA homologue with pleiotropic functions. Biochimie. 1997;79:587-592.

31. Hasselbach L, Haase S, Fischer D, et al. Characterisation of the promoter region of the human DNA-repair gene Rad51. Eur J Gynaecol Oncol. 2005;26:589-598.

32. Thacker J. The RAD51 gene family, genetic instability and cancer. Cancer Lett. 2005;219:125-135.

33. Zhao M, Chen P, Dong Y, et al. Relationship between Rad51 G135C and G172T variants and the susceptibility to cancer: a meta-analysis involving 54 case-control studies. PLoS One. 2014;9(1):e87259.

34. Romanowicz H, Smolarz B, Baszczyński J, et al. Genetics polymorphism in DNA repair genes by base excision repair pathway $(X R C C 1)$ and homologous recombination (XRCC2 and $R A D 51)$ and the risk of breast carcinoma in the Polish population. Pol J Pathol. 2010;61(4): 206-612.

35. Ricks-Santi LJ, Sucheston LE, Yang Y, et al. Association of Rad51 polymorphism with DNA repair in BRCA1 mutation carriers and sporadic breast cancer risk. BMC Cancer. 2011;11:278.

36. Krupa R, Synowiec E, Pawlowska E, et al. Polymorphism of the homologous recombination repair genes RAD51 and XRCC3 in breast cancer. Exp Mol Pathol. 2009;87(1):32-35.

37. Romanowicz-Makowska H, Smolarz B, Kulig A. Germline BRCA1 mutations and $\mathrm{G} / \mathrm{C}$ polymorphism in the $5^{\prime}$-untranslated region of the RAD51 gene in Polish women with breast cancer. Pol J Pathol. 2005; 56(4):161-165.

38. Kadouri L, Kote-Jarai Z, Hubert A, et al. A single-nucleotide polymorphism in the RAD51 gene modifies breast cancer risk in BRCA2 carriers, but not in BRCA1 carriers or noncarriers. Br J Cancer. 2004; 90(10):2002-2005.

39. Smolarz B, Makowska M, Samulak D, et al. Association between polymorphisms of the DNA repair gene RAD51 and ovarian cancer. Pol J Pathol. 2013;64(4):290-295.
40. Romanowicz-Makowska H, Smolarz B, Samulak D, et al. A single nucleotide polymorphism in the $5^{\prime}$ untranslated region of RAD51 and ovarian cancer risk in Polish women. Eur J Gyn Oncol. 2012;33(4):406-410.

41. Silva SN, Tomar M, Paulo C, et al. Breast cancer risk and common single nucleotide polymorphisms in homologous recombination DNA repair pathway genes XRCC2, XRCC3, NBS1 and RAD51. Can Epidemiol. 2010;34(1):85-92.

42. Romanowicz-Makowska H, Samulak D, Michalska M, et al. RAD51 gene polymorphisms and sporadic colorectal cancer risk in Poland. Pol J Pathol. 2012;63(3):193-198.

43. Smolarz B, Samulak D, Michalska M, et al. $135 \mathrm{G}>\mathrm{C}$ and $172 \mathrm{G}>\mathrm{T}$ polymorphism in the $5^{\prime}$ untranslated region of RAD51 and sporadic endometrial cancer risk in Polish women. Pol J Pathol. 2011;62(3):157-162.

44. Romanowicz-Makowska H, Smolarz B, Gajęcka M, et al. Polymorphism of the DNA repair genes RAD51 and XRCC2 in smoking- and drinking-related laryngeal cancer in a Polish population. Arch Med Sci. 2012;8(6):1065-1075.

45. Romanowicz-Makowska H, Smolarz B, Zadrozny M, et al. The association between polymorphisms of the RAD51-G135C, XRCC2-Arg188His and XRCC3-Thr241Met genes and clinico-pathologic features in breast cancer in Poland. Eur J Gyn Oncol. 2012;33(2):145-150.

46. Romanowicz-Makowska H, Smolarz B, Połać I, et al. Single nucleotide polymorphisms of RAD51 G135C, XRCC2 Arg188His and XRCC3 Thr241Met homologous recombination repair genes and the risk of sporadic endometrial cancer in Polish women. J Obs Gyn Res. 2012; 38(6):918-924.

47. Romanowicz-Makowska H, Smolarz B, Zadrozny M, et al. Single nucleotide polymorphisms in the homologous recombination repair genes and breast cancer risk in Polish women. Tohoku J Experim Med. 2011;224(3):201-208.

48. Krivokuca AM, Malisic EJ, Dobricic JD, et al. RAD51 135G $>$ C and TP53 Arg72Pro polymorphisms and susceptibility to breast cancer in Serbian women. Fam Cancer. 2014;13(2):173-180.

49. Yang L, Liu L, Mi YC, et al. Relationship between RAD51-G135C/ XRCC3-C241T polymorphisms and development of acute myeloid leukemia with recurrent chromosome translocation. Zhonghua Xueye Xue Za Zhi. 2011;32(5):299-303.
OncoTargets and Therapy

\section{Publish your work in this journal}

OncoTargets and Therapy is an international, peer-reviewed, open access journal focusing on the pathological basis of all cancers, potential targets for therapy and treatment protocols employed to improve the management of cancer patients. The journal also focuses on the impact of management programs and new therapeutic agents and protocols on

\section{Dovepress}

patient perspectives such as quality of life, adherence and satisfaction. The manuscript management system is completely online and includes a very quick and fair peer-review system, which is all easy to use. Visit http://www.dovepress.com/testimonials.php to read real quotes from published authors. 